RESEARCH ARTICLE

\title{
PSYCHOLOGICAL, SPIRITUAL AND EMOTIONAL RESPONSE TO COVID- 19 PANDEMIC EXPERIENCES AND INTERVENTIONS MADE
}

\author{
Richi Simon', Durdana Ovais², Nilofar Kadeer ${ }^{1}$ \\ 1. Department of Social Work, BSSS, India \\ 2. Department of Commerce, BSSS, India
}

Correspondence: richi_1988@yahoo.co.in

\begin{abstract}
\section{SUMMARY:}

The outbreak of Corona Virus in December 2019, in Wuhan placed a novel challenge in front of mankind. COVID-19 has affected every country in different magnitudes. The absence of vaccine and changed lifestyle suddenly imposed upon masses affected their functioning as well. Those victimized by the virus have their own problems while others also have had their own sufferings.
\end{abstract}

\section{OBJECTIVES:}

Amidst all trials and tests for cure, this paper is an attempt to understand the psychological, spiritual and emotional response to COVID-19 and Government Interventions in India. It also tries to assess the differences in experiences across age, gender and educational qualifications.

\section{DESIGN:}

The study adopts a mixed approach and is an exploratory cross-sectional study. For the purpose of the study, a shortened version of Czech SWSB, RYFF's Psychological Wellbeing 18 point scale and STAI scale were customized for pandemic times, administered towards the end of Lockdown 1.0 in India. After reliability and validity tests, established scales are used to study the variable in the research. For the analysis of data Smart PLS SEM 3.3.2 is used.

SETTING:

General masses of India were a part of the study. A cohort of 100 respondents willing to participate in the survey during the initial 21 days lockdown in India was studied which was selected using snowball sampling.

\section{MAIN OUTCOME MEASURES:}

The study measures the association of psychological, spiritual and emotional response to covid-19 pandemic experiences and also the response to interventions made.

\section{FINDINGS:}

The results show that there is trivial relation of age, education and gender to the experiences of COVID-19. It was also found that Psychological Wellbeing and Spiritual Wellbeing were significantly related to the experiences of COVID-19. CONCLUSION:

Extreme external factors like covid-19 pandemic act as stressors and affect the psychological and spiritual wellbeing of all.

\section{KEYWORDS}

COVID-19 pandemic experience, Psychological wellbeing, Emotional wellbeing, Spiritual wellbeing, Intervention, India 
INTRODUCTION

Covid-19 pandemic created a lot of chaos across the entire globe. Different countries adopted different means to address the situation. Amongst such situations, when most of the research studies were directed towards finding vaccine for coronavirus, less attention was paid to the other aspects of health. The World Health Organization defines health as 'a state of complete physical, mental and social wellbeing and not merely the absence of disease or infirmity'. [1]

\section{COVID-19 PANDEMIC- THE BEGINNING}

Coronaviruses (CoVs) are a large family of viruses mostly affecting the respiratory systems in humans. This has resulted in high mortality with the variants of SARS-CoV and MERS-COV both of which had animal origin and were novel in nature. While SARS-CoV is thought to have originated in civet cats, MERS is believed to have its origin in bats and transmission to camels to humans. The first case of SARSCoV (severe acute respiratory syndrome) was identified in 2003 in China with its first appearance in November 2002 in Guangdong province of southern China. Its spread has been to Toronto, Hong Kong, China, Singapore and Viet Nam. MERS (Middle East Respiratory Syndrome) was identified in Saudi Arabia in 2012. Its largest outbreaks were seen in Saudi Arabia, United Arab Emirates and Republic of Korea. Though MERS did not have any repeated major outbreak, SARS has reappeared 3-4 times in Singapore, Chinese Taipei and southern China.[2], [3]

By 31st December, the Chinese Government had reported an influx of cases of pneumonia with an unidentified reason and, [4] later it was identified as Novel Corona Virus Influenza.

\section{INTERVENTION STRATEGIES}

Though, globally speaking, the preventive strategy adopted for COVID-19 is same as John Haygarth's 18thcentury 'rules of prevention'. [5] It is believed that the Covid-19 outbreak is a stark reminder of the ongoing challenges of emerging and re-emerging infectious pathogens invoking need for constant surveillance, prompt diagnosis, and robust research to know basic biology of new organisms, our susceptibilities to them, and development of countermeasures. Several scientific research studies have been undertaken to find the vaccine and also to search for the right measures and strategies to be adopted in pandemic times. [6] Ambikapanthy \& Krishnamurthy in their mathematical model suggested a lockdown period of up to 42 days for a significant reduction in the number of COVID-19 cases in India along with contact tracing and community screening. [7]

Chakraborty \& Ghosh [8] suggested the following measures that the Government should adopt to reduce Case Fatality Rate (CFR).

1. Enforcing social distancing strategies.

2. Number of people of age group $>65$ years should be specially taken care of and isolated.

3. Lockdown time period should be extended if the country faces a sharp increase in the number of cases and or deaths.

4. The number of hospital beds should be increased by making special health care arrangements.

The COVID-19 pandemic is a global concern that demands for extensive research. India also needs to take effective strategies for handling the present and the projected future outbreaks and problems posed by the pandemic. Keeping in view the COVID-19 pandemic situation, nationwide lockdown was announced by Shri Narendra Modi, the Prime Minister of the nation on 24th March 2020 (Lockdown 1.0) which further was extended on 15th April (Lockdown 2.0) by 19 days to end up on May 3rd, On May 4th the country entered Lockdown 3.0 till May 17th, whereby certain relaxations were given in red, orange and green zones, different guidelines were issued by the Ministry of Home Affairs, on May 18th India entered Lockdown 4.0 which would end by May 31st. In Lockdown 4.0 intra-state and inter-state movements of passenger vehicles and busses were permitted with the consent of the concerned states. The step was taken to secure the physical health of the citizens and stop the spread of the virus.

\section{EFFECTS OF THE PANDEMIC \& LOCKDOWN}

While the direct effect of pandemic is seen in terms of number of people getting infected and projected with death tolls, the effects are not limited to just the physical health aspects. A sudden lockdown in the country caused unrest and panic situation reported across various news channels and newspapers.

Kumar, Nayar \& Koya [9] discussed the adverse effect of lockdown on the migrant rural communities in terms of 
employment, education and emotional turmoil. Many densely populated north Indian States are facing shortage of doctors, hospital beds and equipment. [10] Healthcare services across India have to meet the challenges of workforce shortage, poor infrastructure, absenteeism and quality of care. [11]

The Pandemic was effective enough to bring social, psychological and emotional turmoil. Somewhere, these consequences can be attributed to factors like age and economic status, yet they also were a result of the undeveloped health and emergency services and unpreparedness to address such novel situations.

There were long queves and hustle in the market spaces as the essential supplies were missed. Many had witnessed chaotic situations in the stores and there were many with an out of stock as people rushed to obtain their essentials. [12] With time, problems and panic increased amidst the masses. Be it the essential groceries or medicines, education or examinations, problems of migrants or daily wage earners, everybody had witnessed a change which had an impact on the other aspects of one's health.

The paper attempts to explore 3 aspects of health psychological, emotional and spiritual constructs. Mental health includes our emotional, psychological, and social well-being. It affects how we think, feel, and act. It also helps determine how we handle stress, relate to others, and make choices. The World Health Organization defines mental health as 'a state of well-being in which every individual realizes his or her own potential, can cope with the normal stresses of life, can work productively and fruitfully, and is able to make a contribution to her or his community' Good mental health is integral to human health and well-being.

The four dimensions of psychological health include mental, spiritual, social and physical health. The elements of mindfulness, namely awareness and nonjudgmental acceptance of one's moment-to-moment experience, are regarded as potentially effective antidotes against common forms of psychological distress - rumination, anxiety, worry, fear, anger, and so on - many of which involve the maladaptive tendencies to avoid, suppress, or over-engage with one's distressing thoughts and emotions. [13], [14]

The construct of emotional wellbeing lies within the broader framework of psychological health. Emotional health is a person's ability to accept and manage feelings through challenge and change. Emotional health includes both emotional intelligence and emotional regulation. When the subjective experience of emotions is appropriate over a sustained period, emotional health is thought to be present. Positive affect will be apparent in mundane, daily activities. [15]

Research studies suggest that positive emotions can be the result of certain cognitive or behavioural processes or their cause. Also, involvement in one's community is associated with higher level of happiness and life satisfaction. [16]

It was elaborated that though there is no universally accepted definition of spiritual health, generally people define it with the dimensions of religion, individualism and material-world orientation. It was found that one's spiritual health affects their physical, mental and social health. [17] Spiritual health is not about spirituality but about the connection with self (personal dimension), others (social dimension), the nature (the environment) and the God (transcendental dimension).[18] Many researchers view spiritual health as a key component of health. [19] Spiritual health has a significant positive relation with mental health [20] and physical health. [21]

\section{OBJECTIVES OF THE STUDY}

The current paper is an attempt to compare and contrast the psychological, spiritual and emotional response to pandemic experiences in general and also across different age groups, gender and educational qualifications. It tries to understand the problems faced by the respondents and their response towards the interventions made by the Indian Government during the times of Pandemic.

\section{METHODOLOGY}

It is a mixed study. India where, people are believed to have a strong connection with God and religion, so the researchers wanted to measure and investigate the interplay of these three aspects of health during the times of pandemic.

The study followed a cross-sectional approach whereby Google form was administered using snowball sampling. Starting from the known contacts of the researchers, the respondents were requested to circulate the link of the form next. The process was stopped at the end of 
Lockdown 1.0. i.e., on 15th April, 2020. Eliminating the repeated and incomplete entries, a total of 100 respondents became a part of the study.

\section{Tool for Data Collection}

Self-designed questionnaire was used for the purpose of data collection, which was administered as a Google form. For the purpose of the study, shortened version of Czech
SWSB, RYFF's Psychological Wellbeing 18 point scale and STAI scale were customized for pandemic experiences which was administered towards the end of Lockdown 1.0 in India. The tool comprised of 6 sections - Demographic details, COVID-19 Pandemic Experiences, General Psychological Wellbeing, Spiritual Wellbeing, Emotional Wellbeing, and Response to Intervention.

\section{FIGURE 1: TOOL FOR DATA COLLECTION}



FIGURE 2: PRELIMINARY CONSTRUCTS AND INDICATORS OF THE STUDY

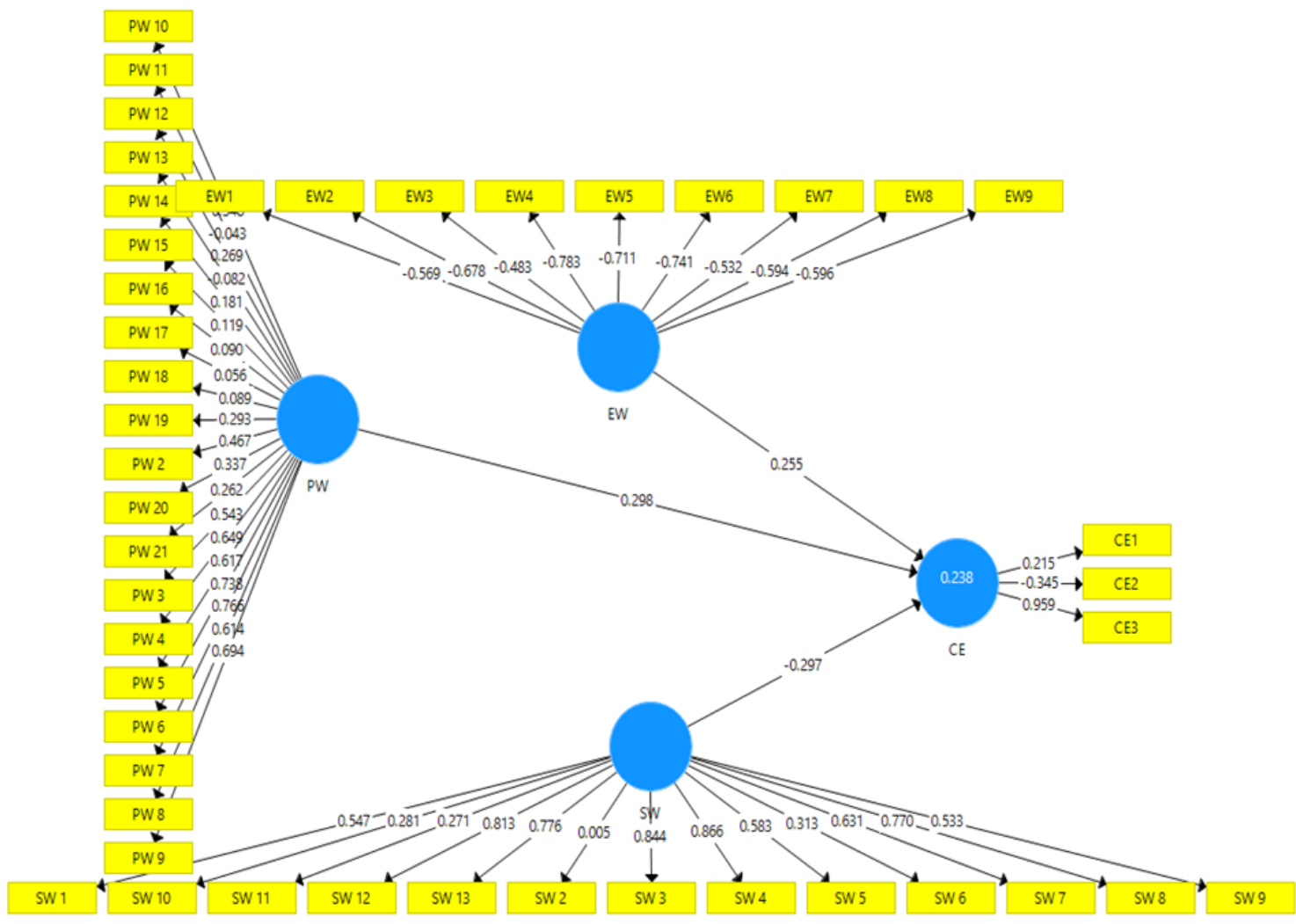




\section{HYPOTHESES}

- H1: Emotional wellbeing is significantly related to COVID-19 experience.

- H2: Psychological wellbeing is significantly related to COVID-19 experience.

- H3: Spiritual wellbeing is significantly related to COVID19 experience.

- H4: Age is significantly related to COVID-19 experience.

- H5: Gender is significantly related to COVID-19 experience.
- H6: Educational Qualifications is significantly related to COVID-19 experience.

The study is based on four constructs namely Covid-19 pandemic experience, emotional wellbeing, psychological wellbeing and spiritual wellbeing. For the purpose of data analysis Smart PLS Sem 3.3.2, the latest software developed by Ringle et al was used. [22] The four constructs were having a total of 45 indicators. After preliminary analysis the items, reliability and validity analysis were conducted and the items with lower loadings were removed. A total of 20 items remained.

FIGURE 3: FINAL CONSTRUCTS AND INDICATORS OF THE STUDY

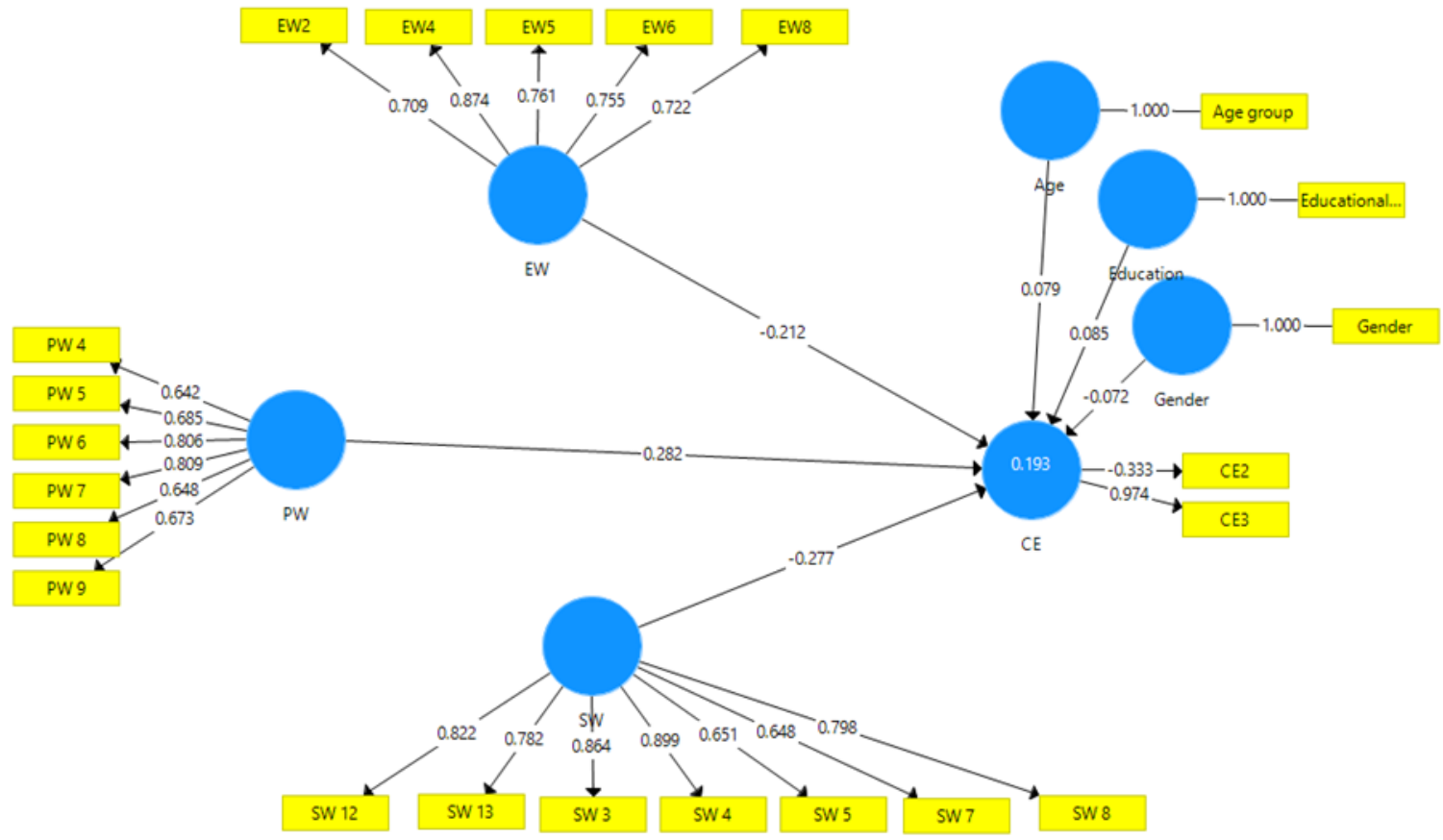

TABLE 1: RELIABILITY TEST

\begin{tabular}{|l|l|l|l|l|}
\hline & $\begin{array}{l}\text { CRONBACH'S } \\
\text { ALPHA }\end{array}$ & RHO_A & $\begin{array}{l}\text { COMPOSITE } \\
\text { RELIABILITY }\end{array}$ & $\begin{array}{l}\text { AVERAGE } \\
\text { VARIANCE } \\
\text { EXTRACTED (AVE) }\end{array}$ \\
\hline CE & -0.247 & 0.659 & 0.352 & 0.523 \\
\hline EW & 0.837 & 0.852 & 0.882 & 0.6 \\
\hline PW & 0.813 & 0.827 & 0.863 & 0.514 \\
\hline SW & 0.894 & 0.906 & 0.918 & 0.617 \\
\hline
\end{tabular}


According to the chronbach alpha the score of CE were less than the threshold value of 0.7 as stated by Hair et al. [23], but a closer look at other reliability analysis method pf Rho A, Composite reliability and AVE the scores are as per the stated limits [24]. All the variables under the study met the stated criteria of acceptability. As such the constructs are meeting the reliability test and further analysis can be undertaken. The value as pre the test of Dijkstra and Henseler's rho A are in accordance with the limit stated that is higher than 0.6 [25]. As the values of AVE are under the limit generally accepted that is 0.5 the results show that convergent validity exists. [26]

\section{RESULTS AND DISCUSSIONS}

The discriminant validity of the study was undertaken to analyse that the constructs under study are different from each other and on the basis of which further statistical analysis can be undertaken or not. Discriminant validity analysis was done by Fornell and Larker criterion and HTMT criterion, the results of which are presented in the tables given below. The figures showed that the constructs under study are different to each other and not overlapping.

TABLE 2: VALIDITY TEST DISCRIMINANT ANALYSIS - FORNELL \& LARCER

\begin{tabular}{|l|l|l|l|l|}
\hline & CE & EW & PW & SW \\
\hline CE & 0.723 & & & \\
\hline EW & -0.115 & 0.775 & & \\
\hline PW & 0.263 & 0.16 & 0.717 & \\
\hline SW & -0.274 & -0.195 & -0.191 & 0.785 \\
\hline
\end{tabular}

TABLE 3: VALIDITY TEST - DISCRIMINANT ANALYSIS HTMT

\begin{tabular}{|l|l|l|l|l|}
\hline & CE & EW & PW & SW \\
\hline CE & & & & \\
\hline EW & 0.288 & & & \\
\hline PW & 0.61 & 0.194 & & \\
\hline SW & 0.559 & 0.264 & 0.206 & \\
\hline
\end{tabular}

TABLE 4: VIF

\begin{tabular}{|l|l|}
\hline & VIF \\
\hline CE2 & 1.012 \\
\hline CE3 & 1.012 \\
\hline EW2 & 1.61 \\
\hline EW4 & 1.811 \\
\hline EW5 & 2.253 \\
\hline EW6 & 1.848 \\
\hline EW8 & 1.519 \\
\hline PW 4 & 1.515 \\
\hline PW 5 & 1.662 \\
\hline PW 6 & 1.994 \\
\hline PW 7 & 1.707 \\
\hline PW 8 & 1.521 \\
\hline PW 9 & 1.614 \\
\hline SW 12 & 2.665 \\
\hline SW 13 & 2.063 \\
\hline SW 3 & 4.544 \\
\hline SW 4 & \\
\hline SW 5 & 1.593 \\
\hline SW 7 & SW 8 \\
\hline
\end{tabular}


TABLE 5: PATH COEFFICIENT

\begin{tabular}{|l|l|l|l|l|l|l|l|}
\hline & $\begin{array}{l}\text { ORIGINAL } \\
\text { SAMPLE } \\
(\mathbf{O})\end{array}$ & $\begin{array}{l}\text { SAMPLE } \\
\text { MEAN } \\
(\mathbf{M})\end{array}$ & $\begin{array}{l}\text { STANDARD } \\
\text { DEVIATION } \\
\text { (STDEV) }\end{array}$ & $\begin{array}{l}\text { T STATISTICS } \\
(\mid \text { O O/STDEV |) }\end{array}$ & $\begin{array}{l}\text { P VALUES } \\
\text { VIDV }\end{array}$ & $\mathbf{2 . 5 0 \%}$ & $\mathbf{9 7 . 5 0 \%}$ \\
\hline Age -> CE & 0.079 & -0.006 & 0.204 & 0.388 & 0.698 & -0.408 & 0.317 \\
\hline EW -> CE & -0.212 & -0.065 & 0.24 & 0.883 & 0.377 & -0.389 & 0.345 \\
\hline Education -> CE & 0.085 & 0.117 & 0.141 & 0.606 & 0.545 & -0.132 & 0.417 \\
\hline Gender -> CE & -0.072 & -0.071 & 0.095 & 0.755 & 0.451 & -0.245 & 0.134 \\
\hline PW -> CE & 0.282 & 0.294 & 0.104 & 2.704 & 0.007 & 0.07 & 0.476 \\
\hline SW -> CE & -0.277 & -0.243 & 0.139 & 1.992 & 0.047 & -0.423 & 0.229 \\
\hline
\end{tabular}

TABLE 6: TOTAL EFFECT

\begin{tabular}{|l|l|l|l|l|l|}
\hline & $\begin{array}{l}\text { ORIGINAL } \\
\text { SAMPLE (O) }\end{array}$ & $\begin{array}{l}\text { SAMPLE } \\
\text { MEAN (M) }\end{array}$ & $\begin{array}{l}\text { STANDARD } \\
\text { DEVIATION } \\
\text { (STDEV) }\end{array}$ & $\begin{array}{l}\text { T STATISTICS } \\
(\mid \text { O/STDEV |) }\end{array}$ & $\begin{array}{l}\text { P } \\
\text { VALUES }\end{array}$ \\
\hline Age -> CE & 0.079 & -0.006 & 0.204 & 0.388 & 0.698 \\
\hline EW -> CE & -0.212 & -0.065 & 0.24 & 0.883 & 0.377 \\
\hline Education -> CE & 0.085 & 0.117 & 0.141 & 0.606 & 0.545 \\
\hline Gender -> CE & -0.072 & -0.071 & 0.095 & 0.755 & 0.451 \\
\hline PW -> CE & 0.282 & 0.294 & 0.104 & 2.704 & 0.007 \\
\hline SW -> CE & -0.277 & -0.243 & 0.139 & 1.992 & 0.047 \\
\hline
\end{tabular}

FIGURE 4: SOURCES OF INFORMATION FOR COVID-19

\section{Major sources of information}

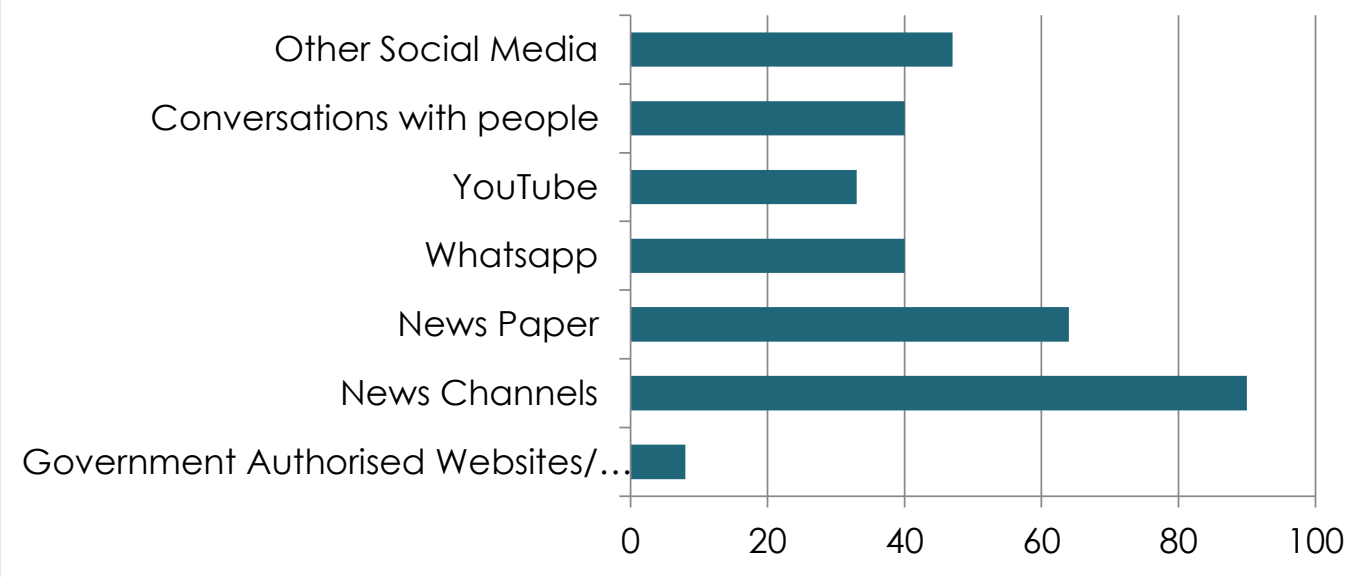


The above table shows the total effect on the constructs under study. From the data analysed it was found that education and gender are relatively more related to the experiences of Covid-19, than age. However, they are trivial. It was also found that psychological wellbeing and spiritual wellbeing were significantly related to the experiences of Covid-19.

The table below shows $R$ square value which is 0.193 . The statistics indicate that 19.3 percent variability in the independent variable is due to the dependent variable.

\section{TABLE 7: R2}

\begin{tabular}{|l|l|l|}
\hline & R SQUARE & R SQUARE ADJUSTED \\
\hline CE & 0.193 & 0.145 \\
\hline
\end{tabular}

The summary of the model fit criteria is given below. To generalise the findings of the data the SRMR value should be below 0.08 . The statistical value derived is slightly more than the stated conservative limits.

TABLE 8: MODEL FIT

\begin{tabular}{|l|l|l|}
\hline & $\begin{array}{l}\text { SATURATED } \\
\text { MODEL }\end{array}$ & ESTIMATED MODEL \\
\hline SRMR & 0.085 & 0.085 \\
\hline d_ULS & 1.989 & 1.989 \\
\hline d_G & 0.695 & 0.695 \\
\hline Chi-Square & 386.143 & 386.143 \\
\hline NFI & 0.669 & 0.669 \\
\hline
\end{tabular}

\section{MAJOR SOURCES OF INFORMATION DURING LOCKDOWN}

During the lockdown period, most of the respondents relied on the information shared through news channels and newspapers, yet very few relied on Government authorized websites and $\mathrm{WHO}$.

\section{PROBLEMS FACED BY THE MASSES DURING THE TIMES OF COVID-19 PANDEMIC}

Most of the respondents faced problems due to no or less mobility. Some faced financial issues and were adversely affected with shortage of groceries. Medical issues like the inability to consult doctors for treatment and unavailability of medicines also prevailed. Respondents were disturbed due to sudden change in lifestyle and experienced stress, emotional turmoil and fear. The extra caution of washing hands, using sanitizers and social distancing with almost no socialization was a little stressful for few respondents. Some even faced difficulties in stopping herd mentality in their families where their family members believed every message on social media platform like whatsapp to be true. Few respondents had strained family relations. The daily wage earners had their own troubles and felt helpless in the times of COVID-19 pandemic.

\section{PERSONAL MEASURES TAKEN BY THE RESPONDENTS}

Figure 5 depicts that majority of the respondents were engaged in wellbeing by staying at homes.

\section{FIGURE 5: PERSONAL CONTRIBUTIONS TO WELLBEING OF MASSES}

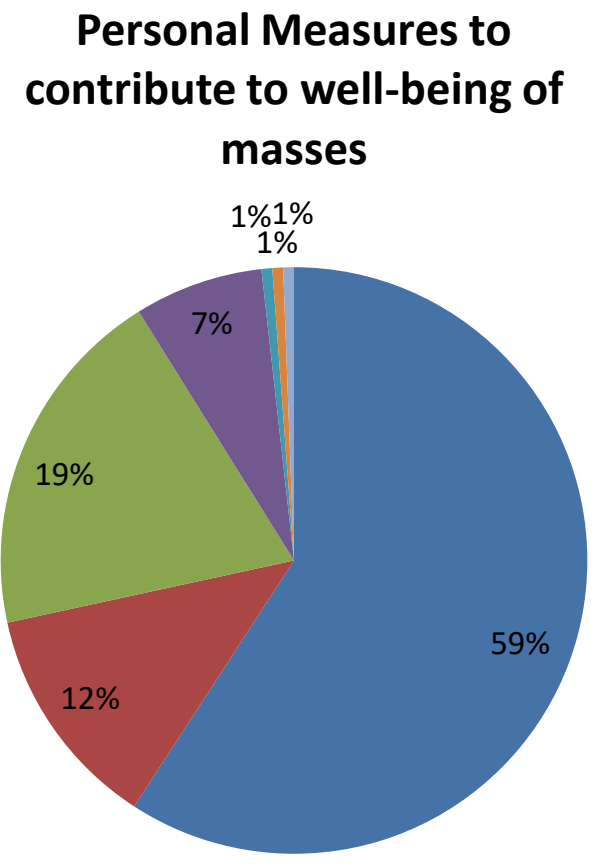

By being at home and stopping the spread of virus

By counselling the masses

By serving the needy and meeting their provisions

By conducting research

Awareness to the marginalized people

Prayers

Helping literature groups to fill in time 


\section{RESPONSE TO GOVERNMENT INTERVENTIONS DURING COVID-19 PANDEMIC}

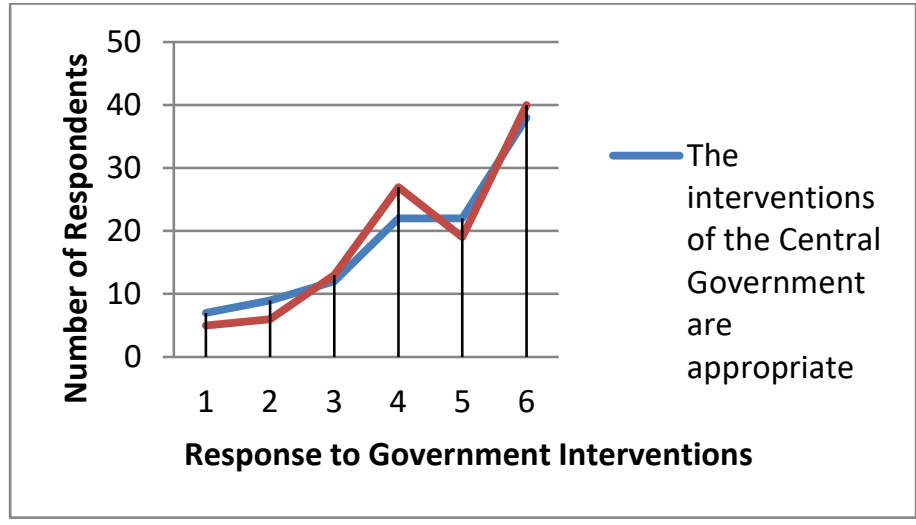

From figure 6 it is clear that majority of the respondents were highly satisfied with the steps taken by the central and state governments with respect to COVID-19 pandemic. Meager $5 \%$ respondents felt that the steps were not apt.

\section{SUGGESTIONS TO MANAGE THE PANDEMIC}

The respondents appreciated the steps taken by the Government like National Lockdown, usage of sanitizers and masks, social distancing of at least 6 feet, and promotion of hand wash for 20 seconds. Some more suggestions as received were:

1. Excessive supply of PPE kits and large scale testing for COVID-19

2. Provision of door to door sanitization, food and medicines.

3. Faster production and supply of ventilators.

4. Creation of more isolation units with proper medical and food provisions.

5. Heavy fines to be imposed upon those who break the social distancing norms which could be used for meeting the safety needs of frontline workers.

6. Ensure all safety equipment for all front line workers.

7. Proper counseling of the masses so that distress can be handled effectively.

8. Providing the labours with social security and helping them to reach their hometown.

9. Strict rules by cyber cell to stop the spread of fake news.

10. Boycotting and discouraging all public meetings.
11. Follow South Korea method and in future give importance to educated ministers and ministers should also work in developing education field and should develop better medical facilities.

12. Not to mix politics with health issues.

13. Stopping of black marketing by shop owners and keepers.

14. Emphasis on exercise, balanced diet and other measures to boost immunity.

15. Taking advice from economists for improving the financial condition of the country.

\section{CONCLUSION}

Covid-19 experiences however disturbing they were projected and felt. The study denotes that age, education and gender were not significantly related to the experiences of COVID-19. Thus, the experiences did not vary across these factors, and though the individual experiences may be different yet statistically it was found that age, gender and educational qualifications could not differentiate the felt experiences. Also, emotional wellbeing was not found significantly related to COVID-19 experiences. However, in the study it was found that psychological wellbeing and spiritual wellbeing were significantly related to the experiences of COVID-19. Therefore, it can be said that the circumstances of lockdown as a result of COVID-19 pandemic strongly affected psychological and spiritual wellbeing. Thus, it can be said that the results are in harmony with the study done by Hilton and Child. [20] Again, as depicted by Hayes \& Feldman [13], Kabat-Zinn and Miller [14], spiritual and emotional health are the constructs of psychological health. Thus, even though the emotional wellbeing was found not to be significantly related to covid-19 experience directly but indirectly.

Even when turbulences of lockdown were felt by everyone, most respondents were satisfied by the efforts of the Government, the results are in accordance with the findings of Helliwell and Putnam [16] where involvement in one's community is associated with higher level of happiness and satisfaction. India being a collectivist country, the response to the interventions were appreciated and the responsibility was equally shared by individuals and organizations. Most respondents appreciated the Government steps and denoted the similar concerns as opined by Chakraborty \& Ghosh. [8] 
It is suggested that further studies can be taken to explore the social aspect of the health, and different time and space zones can be explored for an enriching research experience.

\section{References}

1. Who.int. [cited 2020 Nov 30]. Available from: https://apps.who.int/gb/bd/PDF/bd47/EN/constitution -en.pdf? $\cup a=1$

2. Ho M-S. Severe acute respiratory syndrome (SARS). In: Tropical Infectious Diseases: Principles, Pathogens and Practice. Elsevier; 2011 . p. 392-7.

3. WHO | Middle East respiratory syndrome coronavirus (MERS-CoV) - The Kingdom of Saudi Arabia. 2020 [cited 2020 Nov 30]; Available from: https://www.who.int/csr/don/24-february-2020-merssaudi-arabia/en/

4. Li Q, Guan X, Wu P, Wang X, Zhou L, Tong Y, et al. Early transmission dynamics in Wuhan, China, of novel Coronavirus-infected pneumonia. N Engl J Med. 2020;382(13):1 199-207.

5. Boylston A. John Haygarth's 18th-century "rules of prevention" for eradicating smallpox. J R Soc Med. 2014;107(12):494-9.

6. Fauci AS, Lane HC, Redfield RR. Covid-19 - navigating the uncharted. N Engl J Med. 2020;382(13):1268-9.

7. Ambikapathy B, Krishnamurthy K. Mathematical modelling to assess the impact of lockdown on COVID-19 transmission in India: Model development and validation. JMIR Public Health Surveill. 2020;6(2):e19368.

8. Chakraborty T, Ghosh I. Real-time forecasts and risk assessment of novel coronavirus (COVID-19) cases: A data-driven analysis. Chaos Solitons Fractals. 2020;135(109850):109850.

9. Kumar A, Rajasekharan Nayar K, Koya SF. COVID-19: Challenges and its consequences for rural health care in India. Public Health in Practice.

2020;1 (100009):100009.

10. The implications of COVID-19 for rural India [Internet]. Idronline.org. 2020 [cited 2020 Nov 30]. Available from: https://idronline.org/the-implications-of-covid-19-forrural-india/

11. RHS2019 [Internet]. Nic.in. [cited 2020 Nov 30]. Available from: https://nrhm-
mis.nic.in/Pages/RHS2019.aspx?RootFolder=\%2FRURAL \%2OHEALTH\%2OSTATISTICS\%2F\%28A\%29\%20RHS\%20\%202019\&FolderCTID=0x01200057278FD1EC909F429B03 E86C7A7C3F31 \&View $=\{473 F 70 C 6-7 A 85-47 C 5-A B 5 C-$ B2AD255F29B2\}

12. BBC News. Coronavirus: India enters "total lockdown" after spike in cases. BBC [Internet]. 2020 Mar 25 [cited 2020 Nov 30]; Available from:

https://www.bbc.com/news/world-asia-india52024239

13. Hayes A. M., Feldman G. Clarifying the construct of mindfulness in the context of emotion regulation and the process of change in therapy. Clin Psy Sci Prac.2004; 11: 255-262.

14. Kabat-Zinn J. Full catastrophe living: How to cope with stress, pain and illness using mindfulness meditation. New York: Bantam Dell; 1990.

15. What is emotional health \& 11 activities and assessments to enhance it [Internet].

Positivepsychology.com. 2020 [cited 2020 Nov 30]. Available from:

https://positivepsychology.com/emotional-healthactivities/

16. Helliwell J., Putnam R.D. The social context of wellbeing. In: F.A. Huppert, N. Baylis, and B. Keverne. The science of well-being. Oxford: Oxford University Press; 2005.

17. Ghaderi A, Tabatabaei SM, Nedjat S, Javadi M, Larijani B. Explanatory definition of the concept of spiritual health: a qualitative study in Iran. J Med Ethics Hist Med. 2018;11:3.

18. Gomez R, Fisher J.W. Domains of spiritual well-being and development and validation of the spiritual wellbeing questionnaire. Per Indi Diff. 2003; 35(8): 1975-91

19. Adib-Hajbaghery M, Faraji M. Comparison of happiness and spiritual well-being among the community dwelling elderly and those who lived in sanitariums. Int J Comm Based Nurs Mid.2015; 3(3): 216-26

20. Hilton J.M., Child S.L. Spirituality and the successful aging of older Latinos. Counsel Val. 2014; 59(1): 17-34.

21. Hematti S, Baradaran-Ghahfarokhi M., Khajooei-Fard R., Mohammadi-Bertiani Z. Spiritual well-being for increasing life expectancy in palliative radiotherapy patients: a questionnaire-based study. J Reli Hea. 2015; 54(5): 1563-72. 
22. Ringle CM, Sarstedt M, Mitchell R, Gudergan SP. Partial least squares structural equation modeling in HRM research. int j hum resour manag. 2020;31 (12):1617-43.

23. Hair J, Hult G.T.M., Ringle C, Sarstedt M. A Primer on Partial Least Squares Structural Equation Modeling. Los Angeles: SAGE Publications; 2014

24. Nunnally J.C., Bernstein I.H. Psychological theory. New York: MacGraw-Hill; 1994

25. Dijkstra T. K., Henseler J. Consistent and asymptotically normal PLS estimators for linear structural equations. Comp Stats Data Anal. 2015; 81: 10-23.

26. Henseler J., Ringle C.M., Sarstedt M. A New Criterion for Assessing Discriminant Validity in Variance-based Structural Equation Modeling. J Aca Mark Sci. 2015; 43: $115-35$ 